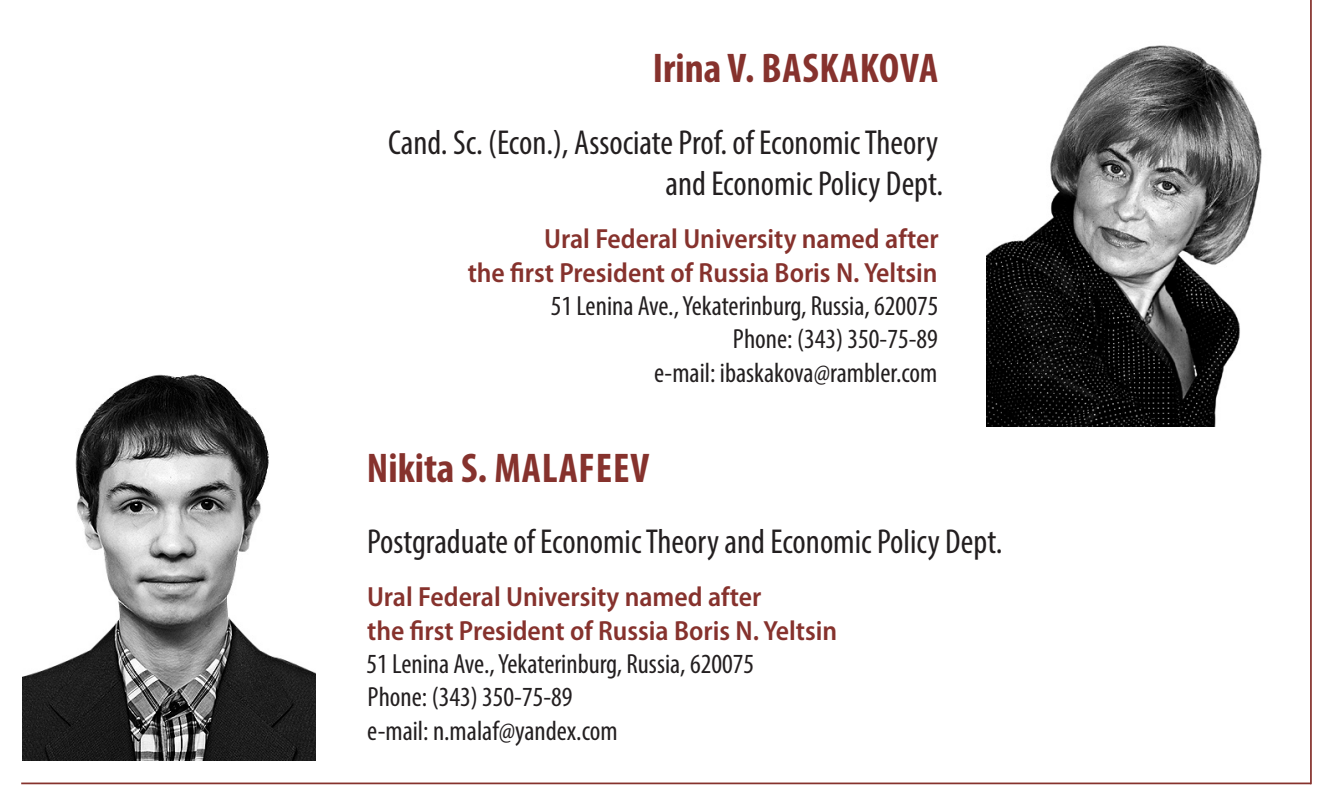

\title{
The Concept of Infrastructure: Definition, Classification and Methodology for Empirical Evaluation
}

\begin{abstract}
Modern economic literature considers infrastructure as one of the key factors behind economic growth, welfare, quality of life, performance of trade, and labour mobility. During economic crises, the issue of infrastructure becomes increasingly relevant, what makes government bodies extremely interested in academic research in this field. The paper aims to clarify the concept of infrastructure and its theoretical foundations. Accordingly, it examines the evolution of approaches to the research on infrastructure and systematizes methods for assessing the infrastructure's contribution to economic development. Having identified two elements, namely a "hard core" and a "flexible shell" in the concept, the authors analyze and describe the mechanism of interaction between them. The results of the study allow building a methodological framework for designing a universal template, which can be used in specific applied research into infrastructure.
\end{abstract}

JEL classification: $\mathrm{H} 54, \mathrm{O} 18$

Keywords: infrastructure; infrastructure capital; public capital; public infrastructure; social overhead capital.

\section{Introduction}

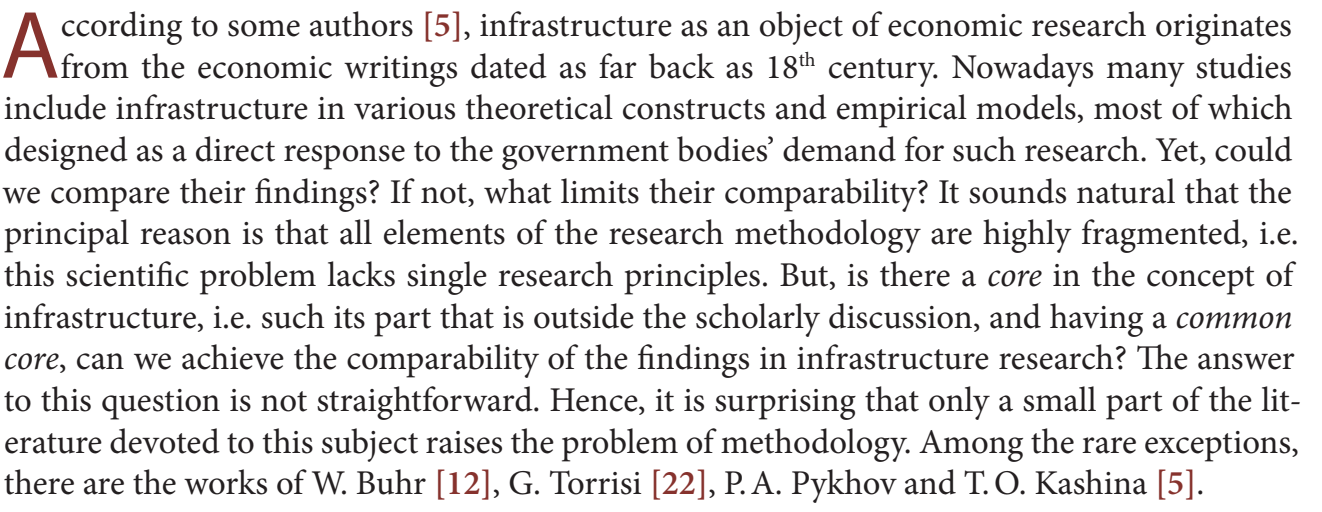


Broad differences in the assessments of the impact of infrastructure on various economic processes leads to a fact that government bodies are not able to take into account the results of the academic research while formulating their infrastructure policy, what significantly undermines their general practical value.

Therefore, the primary objective of this paper is to clarify the concept of infrastructure by $a$. analyzing its historical development; $b$. finding out about the criteria underlying its existing definitions and classifications; $c$. systematizing the methods for assessing the infrastructure's contribution to economic development; $d$. identifying two elements in the concept, namely a "hard core" and a "flexible shell" and examining the mechanism of interaction between them.

Achieving this goal will contribute to resolving the academic debates about the concept of infrastructure and, as a result, allow justifying the possibility of reducing fragmentation within the infrastructure research methodology through the use of a combined approach to its definition, classification and evaluation methods.

\section{The concept of infrastructure: Developmental stages and existing approaches to definition}

The concept of infrastructure has passed through a number of stages in its development.

Stage 1: Initial ideas about the economic nature of infrastructure in the writings of economists of the $18^{\text {th }}$ and $19^{\text {th }}$ centuries. As far back as the $18^{\text {th }}$ century A. Smith [7], justifying the principle of the "invisible hand of the market", assigned the state the function of an infrastructure investor (i.e. the obligation to maintain public facilities and public institutions). According to P. A. Pykhov and T. O. Kashina's clarifications [5. P. 40], K. Marx identified objects of infrastructure with such economic concepts as "general production conditions", "general conditions of the social production process", "material production conditions", "universal means of labour", and "general working conditions".

Stage 2: Understanding infrastructure as social overheads. The term "social overhead capital" has become one of the most important milestones in the understanding of the concept of infrastructure. It grew from P. Samuelson's theory of public goods [6], who understood infrastructure as large investments made solely by the state and laying the preconditions for the successful development of the private sector as they clear the way for production and trade (for instance, roads, irrigation systems, etc.). A. Hirschman [13] pointed to that infrastructure is the basic services, without which primary, secondary and tertiary types of production activities cannot function.

In parallel, the concept of infrastructure was being interpreted within the institutional paradigm by R. Jochimsen [14], who regarded infrastructure as a system of interaction of economic agents, ensuring a link between phases of production and consumption. He highlighted the individual, institutional and material levels of infrastructure.

Stage 3: Considering infrastructure in the context of the theories of economic growth and economic development. Initially, this stage was formed by the works of R. Nurkse [17] (the balanced growth theory), P. Rosenstein-Rodan [18] (the big push theory), W. Rostow [19] (the theory of stages of economic development), who viewed social overhead capital as one of the key sources of economic growth.

P. Rosenstein-Rodan understood infrastructure as a set of conditions necessary for servicing private capital circulation in the main economic sectors and creating favorable conditions for the economy's further development [18. P. 206]. R. Nurske [17] compared infrastructure with the "circulatory" and partly with the "nervous system" of economy. W. Rostow [19] saw infrastructure as an instrument essential to efficiently meet the (social) needs of a growing population.

By 1980s, infrastructure had been predominantly considered as a part of the public capital concept. The study performed by D. Ashauer [9] became the one that triggered a large series of econometric research into infrastructure productivity as a factor affecting the output of the 
private sector of economy. In effect, it gave the green light to the whole infrastructure-based concept of economic development.

Stage 4: Transformation of the concept against the backdrop of the government's refusal of monopoly to develop the infrastructure. Strengthened role of immaterial objects of the infrastructure due to the development of the Internet. Privatization of the state-owned assets, including the infrastructure facilities gave birth to a hybrid form of infrastructure ownership and management, to be more specific, to public-private partnership (PPP). The measurement of the infrastructure effects moved from purely quantitative analysis into combination of quantitative and qualitative indicators (see, for instance, [4]). Infrastructure began to be viewed as a system comprised of material and immaterial objects, and sometimes - only of immaterial ones.

Although infrastructure as a concept has made a long way in its development, researchers have not come closer to formulating its universal definition. Every comprehensive work on this problem establishes its own limits for how infrastructure should be understood. The authors often provide new constructs to counter conventional term "infrastructure", such as, for example, superstructure by J. Tinbergen [21] or suprastructure by P. Nijkamp [16]. These constructs are not accompanied by a proper justification, and thus remain just theoretical speculations of individual researchers. In addition, the academic community carries on discussing the place of infrastructure in the system of "private-public economic benefits", and particularly considering it in the context of the concept "economic service" [1. P. 11-13].

The problem with providing a universal definition to infrastructure is that this implies dealing with the three analytical tasks simultaneously: a. formulating the very concept of infrastructure; b. incorporating theoretical approaches into the definition (for example, the theory of public goods); c. describing the actual state of infrastructure provision, which all together are a virtually unattainable goal for an average researcher.

At present, economic science suggests two leading approaches to defining infrastructure:

The first is an attributive approach, which gained traction in the works of P. RosensteinRodan [18] and R. Jochimsen [14], and, as G. Torrissi [22] argues, prevails. It characterizes infrastructure with regard to the three attributes: technological (capital goods or good, i.e. represented by a large number of units, thus significantly outstripping demand for it), economic (source of external economies, public or merit good and source of external effects) and institutional (infrastructure goods and services as an object of state provision and state control).

The second is a functional approach described in the work of W. Buhr [12].

The second approach is based on the idea that social product is the result of economic agents' interaction, where the contribution of each one is determined by the level of infrastructure provision. Thus, infrastructure is principally characterized by its ability to stimulate and mobilize the agents' potentialities. Every type of infrastructure is determined by the effect produced, i.e. there is an infrastructure oriented towards households, companies, and market generally.

From the authors' viewpoint, each of the two approaches describes only one side of the nature of the infrastructure. Only their combination can provide the research with an exhaustive definition.

\section{Criteria for infrastructure classification}

The classification of the infrastructure lacks a single approach as well.

There are just two criteria for classification: functional nature of the facilities of the infrastructure system and its distinctive features (for instance, network structure or a point object; material or immaterial nature). However, researchers tend to interpret these criteria each in their own way.

Absence of common understanding of the classification criteria is a serious challenge for researchers, especially in the issue of comparing the results. First of all, it affects cross-country 
analysis of the level of infrastructure provision. Here, researchers can only rely on the uniform principles, on which the system of national accounts and collection of statistical data are based (what is true, for example, for OECD countries), because in this case, the types of economic activity can be grouped according to the types of infrastructure using the chosen classification criteria and the goals and objectives of the author. But this is not always possible with respect to developing countries and / or their regions (administrative units).

Table 1 presents the analysis of the infrastructure classifications taken from the works published for the last fifty years. A. Hirschman [13] highlighted that transportation and power supply make up a "hard core" of the concept of infrastructure. It is hardly surprising that some types of infrastructure in classifications by different authors almost coincide in terms of the composition of infrastructure facilities. For instance, roads are part of such types as economic (G. Vaughan-Morris et al [23]), material (R. Jochimsen [14]), "core” (D. Aschauer [9]), basic (J. Sturm et al. [20]), industrial (V. Ye. Popov [3]).

A classification either takes into account all diversity of the infrastructure facilities, or stresses only the most productive part of it (using A. Hirschman's terminology, a "hard core" [13]). In the first case, this is a comprehensive view on infrastructure as an object of research (for instance, R. Jochimsen [14], G. Vaughan-Morris [23]) or a basis for empirical evaluation of the productivity of various types of infrastructure (V.Ye. Popov [3]). In the second case, it is the pure simplification of the procedure of the empirical evaluation (D. Aschauer [9]).

The classification presented in the work of G. Vaughan-Morris [23] corresponds simultaneously to both criteria specified above and represents quite a successful attempt to apply a combined approach, showing the features and functions of individual facilities of infrastructure.

Table 1

Comparative analysis of the approaches to infrastructure classification

\begin{tabular}{|c|c|c|}
\hline Author & Types of infrastructure and their composition & Classification criteria \\
\hline $\begin{array}{l}\text { N. M. Hansen } \\
(1965)\end{array}$ & $\begin{array}{l}\text { 1. Economic (transport: roads, seaports, } \\
\text { airports; } \\
\text { networks: electrical and gas facilities, water, } \\
\text { sewers; transportation of raw materials, ir- } \\
\text { rigation). } \\
\text { 2. Social (schools, hospitals, public order } \\
\text { and law, waste disposal) }\end{array}$ & $\begin{array}{l}\text { Function (economic: direct support of } \\
\text { production activities; } \\
\text { social: improving social comfort, influ- } \\
\text { encing productivity) }\end{array}$ \\
\hline $\begin{array}{l}\text { R. Jochimsen } \\
(1966)\end{array}$ & $\begin{array}{l}\text { 1. Personal (human capital). } \\
\text { 2. Institutional (norms, institutions, pro- } \\
\text { cedures, i.e. economic constitution). } \\
\text { 3. Material (transport, utilities, public ser- } \\
\text { vices, health care, education, communica- } \\
\text { tions, etc.) }\end{array}$ & $\begin{array}{l}\text { Function (personal: determining the } \\
\text { quality of economic agents' values, } \\
\text { institutional: social integration of val- } \\
\text { ues, } \\
\text { material: fulfillment of physical and } \\
\text { social needs) }\end{array}$ \\
\hline $\begin{array}{l}\text { D. Aschauer } \\
(1989)\end{array}$ & $\begin{array}{l}\text { 1. Core (transport: roads, airports, public } \\
\text { transport; networks: electrical and gas fa- } \\
\text { cilities, water, sewers. } \\
\text { 2. Non-core (other) }\end{array}$ & $\begin{array}{l}\text { Function (core: sustainable functioning } \\
\text { of economy) }\end{array}$ \\
\hline $\begin{array}{l}\text { D. Biehl } \\
(1991)\end{array}$ & $\begin{array}{l}\text { 1. Network (roads and railways; network: } \\
\text { communications, electrical and water fa- } \\
\text { cilities). } \\
\text { 2. Point (schools, hospitals, museums) }\end{array}$ & $\begin{array}{l}\text { Feature (structure, necessity for active } \\
\text { involvement of human capital for opera- } \\
\text { tion of an object) }\end{array}$ \\
\hline $\begin{array}{l}\text { Di Palma, } \\
\text { Mazziotta } \\
\text { et al. (1998) }\end{array}$ & $\begin{array}{l}\text { 1. Material (transport, networks: electrical } \\
\text { and water facilities). } \\
\text { 2. Immaterial (centers for innovative re- } \\
\text { search and education centers) }\end{array}$ & Feature (tangible and intangible assets) \\
\hline
\end{tabular}


Table 1 (concluded)

\begin{tabular}{|c|c|c|}
\hline Author & Types of infrastructure and their composition & Classification criteria \\
\hline $\begin{array}{l}\text { V. Ye. Popov } \\
(2009)\end{array}$ & $\begin{array}{l}\text { 1. Production (Transport, communica- } \\
\text { tions, utilities: electricity, gas and water). } \\
\text { 2. Social (public administration, education, } \\
\text { health care, social security and services). } \\
\text { 3. Market (wholesale and retail, catering, } \\
\text { logistics, purchases and financial services) }\end{array}$ & $\begin{array}{l}\text { Function (production: sustainability of } \\
\text { economy; } \\
\text { social: social sustainability; } \\
\text { market: sustainability of market struc- } \\
\text { tures) }\end{array}$ \\
\hline $\begin{array}{l}\text { G. Vaughan- } \\
\text { Morris et al. } \\
(2012)\end{array}$ & $\begin{array}{l}\text { 1. "Hard": } \\
\text { a. Economic (transport, utilities, flood } \\
\text { defences, waste management, communica- } \\
\text { tions). } \\
\text { b. Social (social housing, health facilities, } \\
\text { educational establishments and green in- } \\
\text { frastructure). } \\
\text { c. Industrial (for example, the infrastruc- } \\
\text { ture required in mines or the interconnect- } \\
\text { ing roads within a large factory complex). } \\
\text { 2. "Soft" (government buildings, laws, } \\
\text { rules, systems for upkeeping law and order, } \\
\text { improving educational attainment and ad- } \\
\text { dressing public health issues) }\end{array}$ & $\begin{array}{l}\text { Dual criterion: } \\
\text { a. Function ("hard": operation of eco- } \\
\text { nomic system; "soft": maintenance of } \\
\text { economic and social standards). } \\
\text { b. Feature ("hard": physical objects, } \\
\text { tangible assets; "soft": predominantly } \\
\text { institutions, intangible assets) }\end{array}$ \\
\hline
\end{tabular}

Sources: $[3 ; 9 ; 14 ; 22 ; 23]$.

However, the issues of defining and classifying infrastructure are just a bridge to the two critical stages of academic research: 1) choice of a method for measuring infrastructure endowment and provision, and 2) choice of econometric methods for evaluating the impact of infrastructure on economic performance indicators.

\section{Methods for evaluating endowment and provision of infrastructure and its contribution to economic development}

The objective of measuring infrastructure is either to calculate its stock in a region or a country to add to the statistical data or get a tool to assess the impact of infrastructure on economic performance of a particular area. The second option is more wide-spread, though it does not exclude a possibility to apply both approaches within the scope of one study.

It is worth noting that for such types of infrastructure as immaterial and institutional only indirect measurement is possible through proxy variables. Qualitative analysis of such infrastructure should be based on a whole set of various proxy indicators with the efficiency assessment and justification of their use.

At present, there exist two possible solutions to the problem of measuring infrastructure endowment [22].

The first approach is to measure in monetary terms. This approach has two variations: considering infrastructure as a flow variable (investments into it affect output instantaneously) or as a stock variable (investments affect the future output). Infrastructure stock is calculated by the perpetual inventory method, which consists in adding past gross investments, adjusted for depreciation.

The second approach is to measure in physical terms. It also is effected in two ways: 1) simply in physical terms (capacity of power generation, number of schools); or 2) using the common inventory method, i.e. transforming the physical endowment into monetary terms by attributing the price to each category of good.

The results of measurement of infrastructure endowment in physical and monetary terms may differ significantly. 
The perpetual inventory method requires introducing an assumption concerning the lifespan of the infrastructure, depreciation rate, data on the initial amount of capital stock. Moreover, due to physical and structural specifics, infrastructure facilities cannot be depreciated in the same schemes as production equipment. The method has the quality of overestimating the actual size of the infrastructure capital stock due to inefficiency of a part of investment and some structural causes. It does not take into account how the current stock of infrastructure capital influence possible effects of investing in it and the fact that internal structure matters for network infrastructure. Besides, an adequate calculation using this method requires a long time series of data, which is often not available in developing countries.

Measurement in physical terms, particularly employing the common inventory method, does not have the aforementioned shortcomings, yet the result does not take into account the quality of infrastructure and it is difficult to link it to a concrete measure of economic policy. Therefore, only the use of several approaches simultaneously (i.e. a combined approach to measuring the infrastructure stock) may prove the quality of the research findings.

To date, there are five approaches to studying the connection between the output of the private sector and infrastructure (often only as a share of social capital) [22]:

1) a production function approach;

2) a vector autoregression (VAR) approach;

3) a cost function (or behavioural) approach;

4) a cross-country growth regression approach;

5) an approach based on data-driven regressions.

The method based on production function is applied in empirical studies the most widely [11]. This method regards the stock of infrastructure either as a separate factor in production function of private sector (a pure approach) or as a variable that improves multifactorial productivity (the growth accounting method) [15].

The method of vector autoregression examines relationships between the stock of infrastructure (or, depending on a particular study, any variable which reflects the provision/ endowment of infrastructure in one or another way), production factors and private sector output without introducing any theoretical propositions a priori. The VAR approach, which uses the same set of variables as the method of production function, models every endogenous variable as a function of its own lags and lags of other endogenous variables. And therefore, it can assess whether there is any sort of response from the private sector variables to the stock of infrastructure or not.

The remaining three approaches give elasticities that cannot be compared with the output elasticities of infrastructure obtained using both the methods of production function and vector autoregression.

The cost function approach (or behavioural approach) presented in the work of J. Sturm et al. [20. P. 400-428] uses the functions of costs and revenues to assess the impact of infrastructure on reducing production costs or increasing firms' revenues respectively.

The analysis of cross-country growth regressions uses the regression equations of growth in a reduced form to assess the relationships between per capita output of the private sector and a ratio of state infrastructure investments to GDP. This utilizes spatial or panel data.

The analysis of data-driven regressions is not connected with any theory and often involves indicators of the infrastructure endowment in physical terms.

Application of the approach based on production function is usually associated with the assessment of infrastructure or infrastructure capital using the perpetual inventory method. The evaluation of empirical regressions often involves the infrastructure indicators measured in physical terms.

Concurrent use of the approaches based on production function and vector autoregression (if time series are long enough) helps to solve the problem of the direction of correlation between the stock of infrastructure and output of the private sector. At the same time, the use 
of the results of evaluation of infrastructure endowment in physical terms allows completing the overall picture and improving the general quality of interpretation of the research findings.

Thus, from the authors' viewpoint, the combined approach is a priority both in calculating the data on infrastructure endowment and assessing its effects.

\section{Results and discussion}

Classical algorithm of the infrastructure research methodology consists of four successive stages:

1) Author's definition of the concept of infrastructure that corresponds to the final research objectives and tasks;

2) Classification of the infrastructure facilities with or without the emphasis on a particular type of infrastructure;

3) Selection and justification of the methods for evaluating infrastructure endowment;

4) Selection and justification of author's statistical or econometric methodology for evaluating economic effects generated by infrastructure facilities.

Though providing a researcher with considerable freedom the classical algorithm represents the main source of methodology fragmentation, since with such variability of the methodology elements the end result usually remains an evaluation of a particular author and cannot be adequately generalized with the findings of other studies.

In our view, it is necessary to rethink the existing algorithm in such a way that its ultimate goal would be the maximum permissible defragmentation of the methodology, in other words, to form the methodology foundation, framework, in which there would be enough room for variability. As a consequence, comparability and compatibility of the results of infrastructure research will become possible, what is an essential prerequisite for their use by government authorities when designing economic policy.

The first and crucial step of the new algorithm in the methodology is to develop a generally accepted, standard definition of infrastructure, but not through a rigid formulation reflecting the opinion of a particular researcher, but through establishing a flexible framework for the concept. It is important to set a unified system of coordinates that will integrate disparate approaches and give a researcher certain freedom of choice in filling the definition.

If adhering to this rule, then infrastructure is a multi-level system of facilities, which consist of the tangible and the intangible assets. The characteristics of these facilities are described by two differently directed vectors. The first vector is a range of attributes of infrastructure facilities: technological, economic, and institutional attributes, reflecting its economic nature as a source of external economies of scale, external effects, etc. They remain the same for different types of infrastructures. The second vector is a range of functions of infrastructure facilities, the list of which is determined by the needs of households, enterprises, economy as a whole and varies depending on the type of infrastructures. The set of these infrastructure facilities (of material or immaterial nature) follows directly from the chosen infrastructure classification.

It is important to understand that the concept of infrastructure is not static in time and constantly expands and renews, primarily due to identification of the new classes of infrastructure facilities by economic science.

Yet for the last 70 years, the infrastructure research has specified the set of infrastructure facilities, which is not subject to a scholarly discussion, and, for this reason, may be called (following A. Hirschman [13]) the core of the concept. For instance, the core of the infrastructure concept includes roads and railways, seaports and airports, electricity, gas and water distribution networks. Within a classification, the core is usually related to economic, basic and main infrastructure. The core ensures the integrity of the concept, its sustainability during the evolution of economic science. It serves as a natural methodological foundation helping to succeed in the issue of comparability and compatibility of the findings of infrastructure research. 
Along with the core, the shell can be identified $[2 ; 10]$, which plays the major role in expansion of the concept of infrastructure. The shell of the infrastructure concept can be conditionally divided into inner and outer shells.

The inner shell is principally represented by intangible assets and in classifications is represented by institutional or soft infrastructure: for example, systems of health care, education and public order, systems of laws and regulations, etc. Such infrastructure facilities set out the rules of the game [8], i.e. directly influence the structure of the concept's core

The outer shell is represented by facilities of social infrastructure (for example, government, health care and educational institutions' buildings). It also can comprise facilities of market infrastructure, which is identified by a number of researchers (for instance, by V. Ye. Popov [3]). It is the outer shell that provides the concept with flexibility, which, in turn, leads to differences in definitions and classifications of infrastructure. Outer shell is the most controversial and disputable part of the infrastructure concept, that is why it is necessary to reach a compromise between researchers' viewpoints to make the last step towards the generally accepted and most complete infrastructure concept.

However, for the studies on infrastructure it is not the mere fact of identifying a kind of rigid, constant part in the form of the core and a flexible, changeable part in the form of the shell in the infrastructure concept that is important. The major goal of such division is to reveal the mechanism of interaction between various types of infrastructure related to the core and shell respectively, within an economic system. Our hypothesis is that this mechanism is a closed cycle (see Figure). At this, economic effects generated by the facilities of the basic infrastructure have a significantly smaller time lag compared to the facilities of institutional (inner shell) and social (outer shell) infrastructure.



The concept of infrastructure is not the only one that in one way or the other characterizes infrastructure facilities in economic system. There is no explicit relationship between the next concepts: infrastructure, public infrastructure, infrastructure capital and public capital. These concepts are often used as equivalents, what in our opinion, is erroneous, because it causes additional difficulties for comparison of the results of infrastructure research. We believe that it is possible to distinguish between the four above-mentioned concepts on the basis of two criteria.

The first criterion points to the one, who owns an infrastructure facility: does it belong to the state, or is it a subject of a PPP agreement, or privately owned? Such distinction between public and private sectors of economy is quite justified in this case, because the state 
as an institution bears the major burden of forming the infrastructure - more than $2 / 3$ of the total volume of investments [23].

The second criterion is physical nature of infrastructure facilities. Many researchers (for example, D. Ashauer [9]), for various reasons, consider only that part of the concept of infrastructure, which is represented exclusively by tangible assets, namely its core and partly objects that we attribute to the outer shell.

Taking into account the said criteria a table can be compiled revealing the relationship between existing concepts of infrastructure. The alternative suggested in table 2 is not the only one reasonable, although it can eliminate confusion of the concepts found in economic research that significantly limits the possibilities of comparing their findings.

Table 2

Infrastructure facilities in various concepts

\begin{tabular}{|l|l|l|}
\hline \multirow{2}{*}{ Type of infrastructure facilities } & \multicolumn{2}{c|}{ Institutional involvement } \\
\cline { 2 - 3 } & \multicolumn{1}{c|}{ Public and private sectors } & \multicolumn{1}{c|}{ Only public sector } \\
\hline Tangible and intangible assets & Infrastructure & Public infrastructure \\
\hline Only tangible assets & Infrastructure capital & Public capital \\
\hline
\end{tabular}

The second stage of the algorithm is aimed at standardization of infrastructure classification, i.e. at developing a system of classification giving various possibilities of design to a final researcher, yet without compromising on the comparability with similar classifications. To obtain such system it is required to follow the three steps.

First, to rely on a statistics system existing in a particular country to adequately conduct an empirical study. If necessary, a researcher should manually adjust data to a specific standard (for instance, to the OECD statistical standards).

Second, to apply a combined approach to classification that rests upon both the functional criterion and the criterion of distinctive features of the system of infrastructure facilities. First, it should offer a compromise between different authors' standpoints on infrastructure classification. Secondly, the types formed by such approach should reflect the dual nature of infrastructure facilities, i.e. the same importance of attributes and functions, which they fulfill. For example, economic infrastructure has predominantly a network structure. Social infrastructure is mainly represented by point objects, which cannot function without human capital of the personnel related to them.

Third, to provide for expansion of the classification1, that is division of types of infrastructure into subtypes according to this or that principle/criteria. Firstly, it creates a possibility of deeper empirical analysis, secondly, it means adaptability, i.e. a researcher can include or exclude these or those subtypes with regard to the goals. and tasks of the research.

The third stage of the algorithm focuses on forming a standard set of methods for measuring infrastructure that is actually concurrent use of measurements in monetary and physical terms. Such practice opens up an opportunity to make up for the a priori shortcomings of the perpetual and common inventory methods, and, consequently, to obtain a consistent result, as well as to look at both qualitative and quantitative aspects of the problem.

The fourth stage of the algorithm is to devise a minimum standard set out of the methods for assessing the impact of infrastructure to apply within one research work (or a continuous series of works). This procedure requires the use of at least two econometric methods, which give independent evaluation with different economic interpretation (evaluate different sides of the one phenomenon, as the production function approach and the cost function approach)

${ }^{1}$ At the same time, the classification should not be "inflated", otherwise it will cease to perform its main task, namely to group infrastructure facilities. 
or given there is enough statistics complement each other thus compensating for their own disadvantages (the production function approach and the vector autoregression approach).

Following the steps of the presented algorithm of the methodology allows creating an adequate pattern for an infrastructure researcher, which, on the one hand, establishes limits in the form of a minimum list of elements necessary for justified results, comparable and compatible with other studies, and, on the other hand, provides distinct possibilities to fill the content of research.

Further research should take the following directions. First, actual implementation of the system of infrastructure classification according to the scheme proposed in the paper. Second, putting forward and justifying the criteria for the minimum set of the methods for measuring infrastructure and the methods for assessing its impact, which will provide consistent results. Third, it is necessary to propose adequate tools for statistical and econometric evaluation of economic effects within the presented mechanism of interaction between various types of infrastructure.

\section{Conclusion}

Ideally, a reference definition of infrastructure should reflect the experience of the research on the problem for the past 70-80 years and be maximally compact, because it is just a system of coordinates for a researcher, which takes into consideration a diversity of approaches. Infrastructure classification should mirror the equal importance of features and functions of the system of infrastructure facilities, whereas methods for measuring infrastructure endowment and econometric methods for assessing its impact should be applied in combination: this is an essential condition for their adequacy and consistency. The aforementioned may be called the stages of a reconsidered algorithm of infrastructure methodology, which targets a compromise between authors' viewpoints and maximum permissible comparability of findings of different research on infrastructure. A scholarly research performed according to the specified scheme (pattern) is a direct contribution to designing government economic policy in this field.

Creation of a flexible classification, formation of a minimum set of methods for assessing infrastructure endowment and methods for assessing its impact, empirical evaluation of economic effects of interaction between different levels of infrastructure system make up the issues to be explored in further research.

\section{References}

1. Dyatel Ye. P., Golomolzina N. V., Petrenko D. S. Infraekonomika kak formiruyushheesya napravlenie ekonomicheskoj teorii [Infra-economics as an emerging direction in economics]. Izvestiya Uralskogo gosudarstvennogo ekonomicheskogo universiteta - Journal of the Ural State University of Economics, 2016, no. 5 (67), pp. 5-17.

2. Malafeev N.S. Kontseptsiya infrastruktury v ekonomicheskikh issledovaniyakh [The concept of infrastructure in economic studies]. Materialy XI mezhdunarodnoy konferentsii "Rossiyskie regiony $v$ fokuse peremen" [Proc. of $11^{\text {th }}$ Internat. Conf. "Russian Regions in the Focus of Changes]. Yekaterinburg: UMC UPI Publ., 2017, Vol. 2, pp. 1138-1146.

3. Popov V.Ye. Investitsii v infrastrukturu i ekonomicheskiy rost: regionalnyy aspekt [Investments in infrastructure and economic growth: a regional perspective]. Regionalnaya ekonomika: teoriya i praktika - Regional Economics: Theory and Practice, 2009, no. 1 (94), pp. 59-68.

4. Pykhov P. A., Kashina T. O. Infrastrukturnaya obespechennost' regionov UrFO: metodika otsenki i rezul'taty diagnostiki [Infrastruture security of the Ural regions: Assessment technique and diagnostic results]. Ekonomika regiona - Economy of Region, 2015, no. 3, pp. 66-77.

5. Pykhov P.A., Kashina T.O. Infrastruktura kak objekt ekonomicheskix issledovanij [Infrastructure as an object of economic research]. Zhurnal ekonomicheskoy teorii-Russian Journal of Economic Theory, 2016, no. 1, pp. 39-46. 
6. Samuelson, P. Ekonomika. T. 2 [Economics. Vol. 2]. Moscow: Algon Publ., 1992.

7. Smith A. Issledovanie o prirode i prichinax bogatstva narodov [An Inquiry into the nature and causes of the wealth of nations]. Moscow: Progress Publ., 1962.

8. Anderies J. M., Janssen M. A., Schlager E. Institutions and the Performance of Coupled Infrastructure Systems. International Journal of the Commons, 2016, no. 2, vol. 10, pp. 495-516.

9. Aschauer D. A. Is Public Expenditure Productive? Journal of Monetary Economics, 1989, no. 23 (2), pp. 177-200.

10. Baskakova I., Malafeev N. Infrastructure: Redefining Approaches to the Concept and Classification. Proc. of the $3^{\text {rd }}$ International Multidisciplinary Scientific Conference on Social Sciences and Arts SGEM 2016. Albena, Bulgaria: STEF92 Technology Ltd., 2016, book 2, vol. 5, pp. 361-368.

11. Bom P. R. D., Ligthart J. E. What Have We Learned From the Three Decades of Research on the Productivity of Public Capital? Journal of Economic Surveys, 2014, no. 28 (5), pp. 889-916.

12. Buhr W. What is Infrastructure? Volkswirtschaftliche Diskussionsbeiträge, 2003, no. 107-03. Available at: http://www.wiwi.uni-siegen.de/vwl/repec/sie/papers/107-03.pdf.

13. Hirschman A. O. The Strategy of Economic Development. New Haven: Yale University Press, 1958.

14. Jochimsen, R. Theorie der Infrastruktur: Grundlagen der marktwirtschaftlichen Entwicklung. Tübingen, Deutschland: Universität Tübingen, 1966.

15. Mitra A., Sharma C., Véganzonès-Varoudakis M.-A. Infrastructure, Information \& Communication Technology and Firms' Productive Performance of the Indian Manufacturing. Journal of Policy Modeling, 2016, no. 2, vol. 38, pp. 353-371.

16. Nijkamp P. Infrastructure and Suprastructure in Regional Competition: A Deus Ex Machina? In: Batey P.W.J., Friedrich P. (eds.) Regional Competition. Berlin, Heidelberg, N.Y.: Springer-Verlag, 2000, pp. 87-107.

17. Nurkse R. Problems of Capital Formation in Underdeveloped Countries. Oxford: Oxford Press Publ., 1953.

18. Rosenstein-Rodan P. N. Problems of Industrialization of Eastern and Southeastern Europe. The Economic Journal, 1943, no. 53(210), pp. 202-211.

19. Rostow W. W. The Stages of Economic Growth. The Economic History Review, 1959, no. 12 , pp. $1-16$.

20. Sturm J. E., Kuper G. H., Haan J., de. Modelling Government Investment and Economic Growth on a Macro Level: A Review. In: Brakman S., Ees H. van, Kuipers S.K. (eds.) Market Behaviour and Macroeconomic Modelling. London, UK: MacMillan Press Ltd, 1998, pp. 359-406.

21. Tinbergen J. Shaping the World Economy, Suggestions for an International Economic Policy. New York: The Twentieth Century Fund, 1962.

22. Torrisi G. Public Infrastructure: Definition, Classification and Measurement Issues. MPRA Paper, 2009, no. 12990. Available at: https://mpra.ub.uni-muenchen.de/12990/1/ MPRA_paper_12990.pdf.

23. Vaughan-Morris G. Strategic Infrastructure. Steps to Prioritize and Deliver Infrastructure Effectively and Efficiently. World Economic Forum Report, 2012. Available at: http://www3. weforum.org/docs/WEF_IU_StrategicInfrastructure_Report_2012.pdf. 


\section{Концепция инфраструктуры: определение, классификация и методология оценки}

\section{И. В. Баскакова, Н. С. Малафеев}

В современной экономической литературе инфраструктуре отводится ключевая роль среди факторов, оказывающих влияние на экономический рост, благосостояние, качество жизни, торговые показатели, мобильность трудовых ресурсов. Особенно актуальной проблема формирования инфраструктуры становится в период экономических кризисов, что определяет повышенный интерес государственных органов к академическим подходам к данной теме. Исследование направлено на уточнение терминологии и содержательного фундамента понятия «инфраструктура». Проведен контент-анализ эволюции подходов к изучению инфраструктуры. Систематизированы методы оценки вклада инфраструктуры в экономическое развитие. В концепции инфраструктуры выделены две составляющие: жесткая часть (ядро) и гибкая, обновляющаяся часть (оболочка). Сконструирован механизм взаимодействия инфраструктурных частей. Результатом исследования является построение методологического каркаса, который позволяет создать универсальный шаблон для реализации конкретного, прикладного анализа инфраструктуры.

Ключевые слова: инфраструктура; инфраструктурный капитал; общественный капитал; общественная инфраструктура; общественный накладной капитал.

Источники:

1. Дятел Е.П., Голомолзина Н.В., Петренко Д.С. Инфраэкономика как формирующееся направление экономической теории // Известия Уральского государственного экономического университета. 2016. № 5(67). С. 5-17.

2. Малафеев Н.С. Концепция инфраструктуры в экономических исследованиях // Российские регионы в фокусе перемен: материалы XI междунар. конф. (17-19 ноября 2016 г.): в 2 т. Екатеринбург: УМЦ УПИ, 2017. Т. 2. С. 1138-1146.

3. Попов В.Е. Инвестиции в инфраструктуру и экономический рост: региональный аспект // Региональная экономика: теория и практика. 2009. № 1. С. 59-68.

4. Пыхов П.А., Кашина Т.О. Инфраструктурная обеспеченность регионов УрФО: методика оценки и результаты диагностики // Экономика региона. 2015. № 3. С. 66-77.

5. Пыхов П.А., Кашина Т.О. Инфраструктура как объект экономических исследований // Журнал экономической теории. 2016. № 1. С. 39-46.

6. Самуэльсон П. Экономика: в 2 т. М.: Алгон, 1992. Т. 2.

7. Смит А. Исследование о природе и причинах богатства народов. М.: Прогресс, 1962.

8. Anderies J. M., Janssen M. A., Schlager E. Institutions and the Performance of Coupled Infrastructure Systems // International Journal of the Commons. 2016. No. 2. Vol. 10. P. 495-516.

9. Aschauer D. A. Is Public Expenditure Productive? // Journal of Monetary Economics. 1989. No. 2. Vol. 23. P. 177-200.

10. Baskakova I., Malafeev N. Infrastructure: Redefining Approaches to the Concept and Classification // Proc. of the $3^{\text {rd }}$ International Multidisciplinary Scientific Conference on Social Sciences and Arts SGEM 2016 (August 24-31, 2016): in 4 books. Albena, Bulgaria: STEF92 Technology Ltd., 2016. Book 2. Vol. 5. P. 361-368.

11. Bom P. R. D., Ligthart J. E. What Have We Learned From the Three Decades of Research on the Productivity of Public Capital? // Journal of Economic Surveys. 2014. No. 5. Vol. 28. P. 889-916.

12. Buhr W. What is Infrastructure? // Volkswirtschaftliche Diskussionsbeiträge 2003. No. 107-03. URL: http://www.wiwi.uni-siegen.de/vwl/repec/sie/papers/107-03.pdf.

13. Hirschman A. O. Strategy of Economic Development. New Haven: Yale University Press, 1958.

14. Jochimsen R. Theorie der Infrastruktur: Grundlagen der marktwirtschaftlichen Entwicklung. Tübingen: Universität Tübingen, 1966.

15. Mitra A., Sharma C., Véganzonès-Varoudakis M.-A. Infrastructure, Information \& Communication Technology and Firms' Productive Performance of the Indian Manufacturing // Journal of Policy Modeling. 2016. No. 2. Vol. 38. P. 353-371.

16. Nijkamp P. Infrastructure and Suprastructure in Regional Competition: A Deus Ex Machina? // Regional Competition / ed. by P. W. J. Batey, P. Friedrich. Berlin, Heidelberg, N. Y.: Springer-Verlag, 2000. P. $87-107$.

17. Nurkse R. Problems of Capital Formation in Underdeveloped Countries. Oxford: University Press, 1953. P. 45-97. 
18. Rosenstein-Rodan P. N. Problems of Industrialization of Eastern and Southeastern Europe // The Economic Journal. 1943. No. 210. Vol. 53. P. 202-211.

19. Rostow W. W. The Stages of Economic Growth. London: Cambridge University Press, 1962.

20. Sturm J. E., Kuper G. H., Haan J., de. Modelling Government Investment and Economic Growth on a Macro Level: A Review // Market Behaviour and Macroeconomic Modelling / ed. by S. Brakman, H. van Ees, S. K. Kuipers. London, UK: MacMillan Press Ltd, 1998. P. 359-406.

21. Tinbergen J. Shaping the World Economy, Suggestions for an International Economic Policy. N. Y.: The Twentieth Century Fund, 1962.

22. Torrisi G. Public Infrastructure: Definition, Classification and Measurement Issues // MPRA Paper. 2009. No. 12990. URL: https://mpra.ub.uni-muenchen.de/12990/1/MPRA_paper_12990.pdf.

23. Vaughan-Morris G. Strategic Infrastructure. Steps to Prioritize and Deliver Infrastructure Effectively and Efficiently // World Economic Forum Report. 2012. URL: http://www3.weforum.org/docs/ WEF_IU_StrategicInfrastructure_Report_2012.pdf.

Сведения об авторах:

И. В. Баскакова, канд. экон. наук, доцент кафедры экономической теории и экономической политики

Уральский федеральный университет имени первого Президента России Б. Н. Ельцина

Контактный телефон: (343) 350-75-89

e-mail: ibaskakova@rambler.ru

Н. С. Малафеев, аспирант кафедры экономической теории и экономической политики

Контактный телефон: (343) 350-75-89

e-mail: n.malaf@yandex.com

Уральский федеральный университет имени первого Президента России Б.Н. Ельцина 620075, г. Екатеринбург, ул. Ленина, д. 51

Ссылка для ииттирования:

Baskakova I.V., Malafeev N.S. The Concept of Infrastructure: Definition, Classification and Methodology for Empirical Evaluation // Известия Уральского государственного экономического университета. 2017. № 3 (71). C. 29-41.

For citation:

Baskakova I. V., Malafeev N. S. The Concept of Infrastructure: Definition, Classification and Methodology for Empirical Evaluation. Izvestiya Uralskogo gosudarstvennogo ekonomicheskogo universiteta - Journal of the Ural State University of Economics, 2017, no. 3(71), pp. 29-41. 